\title{
Data report: rate- and state-dependent friction parameters of core samples from Site C0019, IODP Expedition 343 (JFAST) ${ }^{1}$
}

\author{
Matt J. Ikari²
}

\section{Chapter contents}

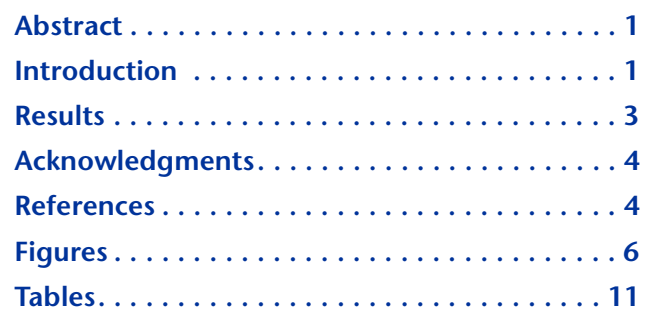

${ }^{1}$ Ikari, M.J., 2015. Data report: rate- and statedependent friction parameters of core samples from Site C0019, IODP Expedition 343 (JFAST). In Chester, F.M., Mori, J., Eguchi, N., Toczko, S., and the Expedition 343/343T Scientists, Proc. IODP, 343/343T: Tokyo (Integrated Ocean Drilling Program Management International, Inc.). doi:10.2204/iodp.proc.343343T.203.2015 2MARUM, Center for Marine Environmental Sciences, University of Bremen, D-28359 Bremen, Germany.mikari@marum.de

\begin{abstract}
This report explains shearing tests conducted on samples collected throughout the main cored interval at Site C0019 during Integrated Ocean Drilling Program Expedition 343, the Japan Trench Fast Drilling Project. This site is located within the region of high coseismic slip during the 2011 Tohoku earthquake that reached the ocean floor at the Japan Trench. Results of velocitystepping tests within $0.1-30 \mu \mathrm{m} / \mathrm{s}$ on both intact and powdered samples allowed quantification of the rate- and state-dependent friction constitutive parameters $a-b, a, b_{1}, b_{2}, D_{\mathrm{c} 1}$ and $D_{\mathrm{c} 2}$ by inverse modeling techniques. Also reported here are measurements of the initial friction prior to each step $\left(\mu_{\circ}\right)$ and the slip-dependence of friction $(\eta)$, which were used as input parameters to the model. Downhole patterns of friction parameters are observed to correlate consistently with lithology. For powdered samples, the fault zone, a siliceous mudstone $\sim 2 \mathrm{~m}$ below the fault zone, and three pelagic clay samples can be distinguished from hanging wall and underthrust footwall siliceous mudstones by lower $a$, lower $b$, higher $a-b$. These results indicate a tendency for velocity strengthening, lower friction, and higher $\eta$, which indicates a tendency for slip-hardening. Intact samples show the same patterns, albeit with fewer data points. Aside from the lithologic control, strong downhole trends in the friction parameters are not observed.
\end{abstract}

\section{Introduction}

The slip behavior of major fault zones, especially at shallow depths, is controlled by the frictional behavior of the active shear zone. The $2011 \mathrm{Mw} 9.0$ Tohoku earthquake produced largely unexpected 30-80 $\mathrm{m}$ of shallow coseismic slip that breached the Japan Trench (Fujiwara et al., 2011; Ide et al., 2011; Ito et al., 2011). That the shallowest reaches of the Japan Trench in the Tohoku area facilitated such a large amount of coseismic slip propagation is inconsistent with current understanding of fault mechanics, and explaining this phenomenon therefore requires thorough characterization of megathrust fault zone frictional properties in this region (e.g., Lay and Kanamori, 2011). Drilling during Integrated Ocean Drilling Program (IODP) Expedition 343, the Japan Trench Fast Drilling Project (JFAST) penetrated the toe of the prism at the Japan Trench subduction zone $\sim 5 \mathrm{~km}$ landward of the trench axis, within the area of high coseismic slip and directly 
updip from the Tohoku earthquake hypocenter (Fig. F1). Successful recovery of core samples of the fault zone that hosted the 2011 Tohoku earthquake, as well as the surrounding wall rocks, in the $\sim 840 \mathrm{~m}$ deep borehole has provided the opportunity to investigate the frictional properties of the shallow plate boundary megathrust in the Tohoku.

\section{Sample descriptions}

The sample suite in this study consists of 21 samples recovered by rotary barrel coring between 648 and 837 meters below seafloor (mbsf) (Table T1). Seventeen of these samples are siliceous mudstones that make up the hanging wall prism and underthrust footwall (lithologic Units 2, 3, and 5) and are relatively structureless (see the "Site C0019" chapter [Expedition 343/343T Scientists, 2013b]). The remaining samples include one sample from a highly sheared scaly clay layer (Unit 4) interpreted to be the plate boundary fault zone at 821.5-822.5 mbsf (Chester et al., 2013), and three samples of a multicolored, stratified pelagic clay layer located $\sim 10 \mathrm{~m}$ below the fault zone (Unit 6). Unlike the fault zone, the pelagic clay exhibits no shear fabric (see the "Site C0019" chapter [Expedition 343/343T Scientists, $2013 \mathrm{~b}])$. Seven of the samples were recovered in a sufficient condition to be tested intact: four hanging wall mudstones, one from the fault zone, and one footwall mudstone. The final intact sample was recovered in Core 343-C0019E-21R from the bottom of the borehole; however, this sample is a mudstone rather than the chert that defines Unit 7, and therefore is probably a Unit 3 sample that fell into the borehole. All 21 samples were tested as gouge powders; therefore, the seven intact samples can be directly compared with a powdered sample of equivalent composition.

\section{Rate- and state-dependent friction}

Many studies over the years have demonstrated with laboratory shearing experiments that fault strength is dependent on the sliding velocity (see Marone, 1998, and references therein). In such experiments, the coefficient of sliding friction $\mu$ is calculated from the measured shear strength:

$$
\mu=\frac{\tau}{\sigma_{\mathrm{n}}^{\prime}} .
$$

The velocity dependence of friction is then evaluated by instantaneously increasing (or sometimes decreasing) the sliding velocity from an initial value $v_{0}$ to a new value $v$ in a stepwise fashion. The frictional response to an imposed velocity step is described by an empirically derived constitutive friction law (Dieterich, 1979, 1981):

$$
\begin{gathered}
\mu=\mu_{0}+a \ln \left(\frac{v}{v_{0}}\right)+b_{1} \ln \left(\frac{v_{0} \theta_{1}}{D_{\mathrm{c} 1}}\right)+b_{2} \ln \left(\frac{v_{0} \theta_{2}}{D_{\mathrm{c} 2}}\right), \\
\frac{d \theta_{\mathrm{i}}}{d t}=1-\frac{v \theta_{\mathrm{i}}}{D_{\mathrm{ci}}}, \mathrm{i}=1,2,
\end{gathered}
$$

where $a, b_{1}$, and $b_{2}$ are unitless constants and $D_{\mathrm{c} 1}$ and $D_{\mathrm{c} 2}$ are critical slip distances, over which friction evolves over durations measured as $\theta_{1}$ and $\theta_{2}$, the state variables (Fig. F2). Because the frictional response depends on both the velocity $v$ and the state variable $\theta$, this formulation is known as rate- and state-dependent friction (RSF).

If the friction level at the higher velocity $v$ has reached steady-state, Equations 2 and 3 can be reduced to:

$$
a-b=\frac{\Delta \mu_{\mathrm{ss}}}{\Delta \ln v^{\prime}}
$$

where the parameter $a-b$ quantifies the rate-dependence of friction. This is the most important and widely used parameter because it controls the occurrence of slip instability that results in earthquake nucleation (e.g., Scholz, 1998). If $a-b>0$, known as velocity-strengthening friction, slip is expected to be stable. On the other hand, $a-b<0$ defines velocityweakening behavior, which is a necessary condition for unstable slip. The RSF parameters, including $a-b$, have been used in numerical modeling studies to successfully simulate and describe a wide range of fault-slip phenomena, including earthquake nucleation and rupture (e.g., Okubo, 1989; Dieterich, 1992), afterslip (e.g., Perfettini and Avouac, 2007), and transient slow slip events (e.g., Liu and Rice, 2009).

\section{Experimental methods}

Laboratory friction experiments were performed by shearing the samples in a single direct shear device (see Ikari and Kopf, 2011) (Fig. F3). In this apparatus, the sample volume is a vertically oriented cylinder $25 \mathrm{~mm}$ in diameter and with a height of $\sim 12-20 \mathrm{~mm}$ within a cell consisting of two flat-lying steel plates. Intact samples were carved from whole-round cores to fit exactly into the sample cell. Powdered samples were prepared by drying the samples at room temperature, disaggregating by hand in a mortar and pestle, and sieving to a maximum grain size of 125 $\mu \mathrm{m}$. The powders were then mixed with a small amount of $3.5 \% \mathrm{NaCl}$ brine to form a paste, which was then pressed into the sample cell. Samples were then loaded to a target normal stress $\left(\sigma_{n}\right)$ of $\sim 5-7$ $\mathrm{MPa}$ to match in situ effective vertical stresses estimated from shipboard measurements of bulk density 
(minus seawater density) and assuming hydrostatic fluid pressure conditions (see the "Expedition 343/ $343 T$ summary" and "Site C0019" chapters [Expedition 343/343T Scientists, 2013a, 2013b]) (Table T1). Although the pore pressure cannot be directly controlled in this system, samples were allowed to consolidate overnight after application of normal load and allowed to freely drain through porous metal frits at the top and bottom of the sample. Shearing was only initiated after the sample height reached a steady value, indicating that any excess pore pressure had dissipated and the applied normal stress $\left(\sigma_{n}\right)$ is equal to the effective normal stress $\left(\sigma_{n}{ }^{\prime}\right)$. Shear is induced by relative displacement of the plates normal to the cylinder axis; for intact samples this means that the shear plane is not necessarily aligned with sample fabric, and this difference depends on the fabric dip. Deformation is in the apparatus is planar and therefore enforced to be localized. All tests were conducted under fluid-saturated conditions with $3.5 \% \mathrm{NaCl}$ brine as the pore fluid. To ensure saturation during the tests, the sample cell is submerged in a pore fluid reservoir.

The experimental procedure involves shearing at a constant rate of $10 \mu \mathrm{m} / \mathrm{s}$ to a displacement of $\sim 5$ $\mathrm{mm}$, in order to reach an approximate steady-state shear strength in which low-displacement effects (e.g., from fracturing near the peak strength) are minimized. In order to measure the velocity (or rate) dependence of friction, the shearing velocity was then increased in a series of steps within the range $0.1-30 \mu \mathrm{m} / \mathrm{s}$ (Fig. F3). The upstep velocity is $v=\sim 3 v_{0}$, where $v_{0}$ is the initial velocity of each step. Although the parameter $a-b$ may be calculated by directly measuring the steady-state friction change from a velocity step (Equation 4), the individual RSF parameters $a, b_{1}, b_{2}, D_{\mathrm{c} 1}$, and $D_{\mathrm{c} 2}$ must be calculated with modeling techniques due to covariance. An expression for the system stiffness $k$ (friction/displacement) is incorporated:

$$
\frac{d \mu}{d t}=k\left(v_{\mathrm{lp}}-v\right)
$$

where $\left(v_{1 \mathrm{p}}-v\right)$ is the difference between true slip velocity $v$ and the remotely recorded load point velocity $v_{\text {Ip }}$ due to apparatus deformation. The system stiffness includes the combined effects of apparatus and sample stiffness; for most testing equipment this is dominated by the apparatus stiffness. Equations 2, 3 , and 5 are solved with a fifth-order Runge-Kutta numerical integration, and best-fit RSF parameters are obtained by solving the inverse problem with an iterative least-squares method (Fig. F3) (Reinen and
Weeks, 1993). Due to variations in the experimental data caused by signal noise or excursions in the measurement, standard deviations for the modeled values are also calculated. In some cases, the data are well fit using one state variable, where $b_{2}=0$. Input parameters for the inversion include visual estimations of the RSF parameters, the initial friction level immediately preceding the velocity step $\mu_{0}$, friction slip dependence $\eta=\mathrm{d} \mu / \mathrm{d} x$ at $v$ (where $x$ is slip displacement), and the system stiffness $k$ (friction/displacement).

\section{Results}

\section{Powdered samples}

Values of $a$ generally range between 0.003 to 0.009 for all samples except the fault zone sample from Section 343-C0019E-17R-1, the three pelagic clay samples from Section 20R-2, and the sample from Section 18R-1 from Unit 5 mudstones located $\sim 2 \mathrm{~m}$ below the fault zone. These samples exhibited clearly lower values of $a<0.004$ (Fig. F4; Table T2). Large scatter between -0.003 and 0.011 is observed for $b_{1}$ and $b_{2}$, with generally lower values occurring in the fault zone and pelagic clays. Instances of negative $b$ are observed mostly in the white pelagic clay. For the critical slip distances, $D_{\mathrm{c} 1}$ is typically less than $\sim 15$ $\mu \mathrm{m}$ and generally smaller than $D_{\mathrm{c} 2}$, which mostly clusters between $\sim 40$ and $200 \mu \mathrm{m}$. Larger values of $D_{\mathrm{c} 1}$ ranging from $\sim 20 \mu \mathrm{m}$ up to several hundred micrometers are observed again for the fault zone, pelagic clay, and Section 18R-1 sample; however, in these cases the data were fit with one state variable, suggesting that the longer $D_{c}$ is a typical value. Mostly velocity-weakening friction is observed throughout the borehole, with $a-b$ approximately ranging between -0.01 and 0.005 . Within the scatter, $a-b$ appears to slightly increase from $\sim 650$ to 720 mbsf. The fault zone, pelagic clays, and 18R-1 sample tend to exhibit velocity-strengthening behavior $(a-b$ up to $\sim 0.004$ ), but a few occurrences of velocity weakening are still observed in these samples. Initial friction values $\mu_{0}$ are consistently between 0.43 and 0.58 and appear to slightly decrease from $\sim 650$ to 720 mbsf before becoming relatively constant downhole. Notably weak values of $0.18-0.29$ are observed for the fault zone, Sample18R-1, and pelagic clay (Fig. F4, Table T3). The friction slip dependence parameter $\eta$ shows a wide scatter between -0.025 and $0.01 \mathrm{~mm}^{-1}$, but mostly negative values indicating slip-weakening friction. Again, exceptions include the fault zone, Sample 18R-1, and pelagic clay for which most of the slip-hardening is observed. 


\section{Intact samples}

Due to the smaller number of samples, downhole trends are more difficult to identify for intact samples, but they exhibit many of the same characteristics as the powdered samples. No intact samples of the pelagic clay or Section 343-C0019E-18R-1 were tested, but one sample of the fault zone was tested in an intact state. For the intact wall rock mudstones (Units 3 and 5), $a$ ranges from $0.003-0.007$ but is $<0.0024$ in the fault zone (Fig. F5; Table T4). Both $b_{1}$ and $b_{2}$ range from 0.001 to 0.007 ; no negative values of $b$ are observed. Values of $b$ are clearly lower for the fault zone, ranging from 0.0004 to 0.0014 . For mudstone samples, $D_{\mathrm{c} 1}$ is usually less than $\sim 15 \mu \mathrm{m}$, and values $<10 \mu \mathrm{m}$ are common, whereas $D_{\mathrm{c} 2}$ values range from $\sim 40$ to $200 \mu \mathrm{m}$. Similar to observations from the powdered samples, the intact fault zone sample was well fit with one state variable; therefore, its $D_{\text {c }}$ values of 35-90 $\mu \mathrm{m}$ match closely with the $D_{\mathrm{c} 2}$ values of the mudstone wall rock. Velocity weakening is common for intact samples, with $a-b$ as low as -0.008 . The fault zone sample is velocity neutral to velocity strengthening $(a-b=0-0.002)$; however, some instances of velocity strengthening are also observed in the wall rock. The range of initial friction values for the mudstones is $\sim 0.40-0.55$, slightly lower than the range for powdered samples (Fig. F5; Table T5). Initial friction values for the fault zone cluster tightly at $\mu_{0}=0.21$. Finally, the friction slip dependence ranges from -0.02 to $0.02 \mathrm{~mm}^{-1}$ and appears to increase with depth such that the fault zone and the mudstone below it (Section 343-C0019E20R-1) exhibit only slip-hardening behavior, whereas the shallow samples exhibit slip weakening.

\section{Acknowledgments}

I thank Achim Kopf, Chris Marone, and André Niemeijer for helpful discussions and for providing access to the experimental apparatus and modeling software. Samples were provided by the Integrated Ocean Drilling Program (IODP) and collected during Expedition 343. This work was supported by the Deutsche Forschungsgemeinschaft Grant \#IK107/1-1 to M.J.I.

\section{References}

Chester, F.M., Rowe, C., Ujiie, K., Kirkpatrick, J., Regalla, C., Remitti, F., Moore, J.C., Toy, V., Wolfson-Schwehr, M., Bose, S., Kameda, J., Mori, J.J., Brodsky, E.E., Eguchi, N., Toczko, S., and the Expedition 343 and 343T Scien- tists, 2013. Structure and composition of the plateboundary slip zone for the 2011 Tohoku-oki Earthquake. Science, 342(6163):1208-1211. doi:10.1126/science. 1243719

Dieterich, J.H., 1979. Modeling of rock friction: 1. Experimental results and constitutive equations. J. Geophys. Res.: Solid Earth, 84(B5):2161-2168. doi:10.1029/ JB084iB05p02161

Dieterich, J.H., 1981. Constitutive properties of faults with simulated gouge. In Carter, N.L., Friedman, M., Logan, J.M., and Stearns, D.W. (Eds.), Mechanical Behavior of Crustal Rocks: The Handin Volume. Geophys. Monogr., 24:103-120. http://onlinelibrary.wiley.com/doi/ 10.1029/GM024p0103/summary

Dieterich, J.H., 1992. Earthquake nucleation on faults with rate- and state-dependent strength. Tectonophysics, 211(1-4):115-134. doi:10.1016/0040-1951(92)90055-B

Expedition 343/343T Scientists, 2013a. Expedition 343/ 343T summary. In Chester, F.M., Mori, J., Eguchi, N., Toczko, S., and the Expedition 343/343T Scientists, Proc. IODP, 343/343T: Tokyo (Integrated Ocean Drilling Program Management International, Inc.). doi:10.2204/ iodp.proc.343343T.101.2013

Expedition 343/343T Scientists, 2013b. Site C0019. In Chester, F.M., Mori, J., Eguchi, N., Toczko, S., and the Expedition 343/343T Scientists, Proc. IODP, 343/343T: Tokyo (Integrated Ocean Drilling Program Management International, Inc.). doi:10.2204/ iodp.proc.343343T.103.2013

Fujiwara, T., Kodaira, S., No, T., Kaiho, Y., Takahashi, N., and Kaneda, Y., 2011. The 2011 Tohoku-Oki earthquake: displacement reaching the trench axis. Science, 334(6060):1240. doi:10.1126/science.1211554

Ide, S., Baltay, A., and Beroza, G.C., 2011. Shallow dynamic overshoot and energetic deep rupture in the $2011 \mathrm{Mw}$ 9.0 Tohoku-Oki earthquake. Science, 332(6036):14261429. doi:10.1126/science.1207020

Ikari, M.J., and Kopf, A.J., 2011. Cohesive strength of clayrich sediment. Geophys. Res. Lett., 38(16):L16309. doi:10.1029/2011GL047918

Ito, Y., Tsuji, T., Osada, Y., Kido, M., Inazu, D., Hayashi, Y., Tsushima, H., Hino, R., and Fujimoto, H., 2011. Frontal wedge deformation near the source region of the 2011 Tohoku-Oki earthquake. Geophys. Res. Lett., 38(7):L00G05. doi:10.1029/2011GL048355

Lay, T., and Kanamori, H., 2011. Insights from the great 2011 Japan earthquake. Phys. Today, 64(12):33-39. doi:10.1063/PT.3.1361

Liu, Y., and Rice, J.R., 2009. Slow slip predictions based on granite and gabbro friction data compared to GPS measurements in northern Cascadia. J. Geophys. Res.: Solid Earth, 114(B09407). doi:10.1029/2008JB006142

Marone, C., 1998. Laboratory-derived friction laws and their application to seismic faulting. Annu. Rev. Earth Planet. Sci., 26:643-696. doi:10.1146/ annurev.earth.26.1.643 
Okubo, P.G., 1989. Dynamic rupture modeling with laboratory-derived constitutive relations. J. Geophys. Res.: Solid Earth, 94(B9):12321-12335. doi:10.1029/ JB094iB09p12321

Perfettini, H., and Avouac, J.-P., 2007. Modeling afterslip and aftershocks following the 1992 Landers earthquake. J. Geophys. Res.: Solid Earth, 112(B7):B07409. doi:10.1029/2006JB004399

Reinen, L.A., and Weeks, J.D., 1993. Determination of rock friction constitutive parameters using an iterative least squares inversion method. J. Geophys. Res.: Solid Earth, 98(B9):15937-15950. doi:10.1029/93JB00780

Scholz, C.H., 1998. Earthquakes and friction laws. Nature, 391(6662):37-42. doi:10.1038/34097

Initial receipt: 11 June 2014

Acceptance: 12 March 2015

Publication: 15 June 2015

MS 343343T-203 
Figure F1. Map of the Tohoku area of the Japan Trench, showing the epicenter of the 2011 Tohoku earthquake, the location of Site C0019, and the location of seismic reflection Line HD33B. Lower panel is a cross-sectional profile of the toe of the Japan Trench prism, showing seismic reflection data from Line HD33B and the depth and location of the JFAST borehole, Hole C0019E. VE = vertical exaggeration. Modified from the "Expedition 343/343T summary" chapter (Expedition 343/343T Scientists, 2013a).

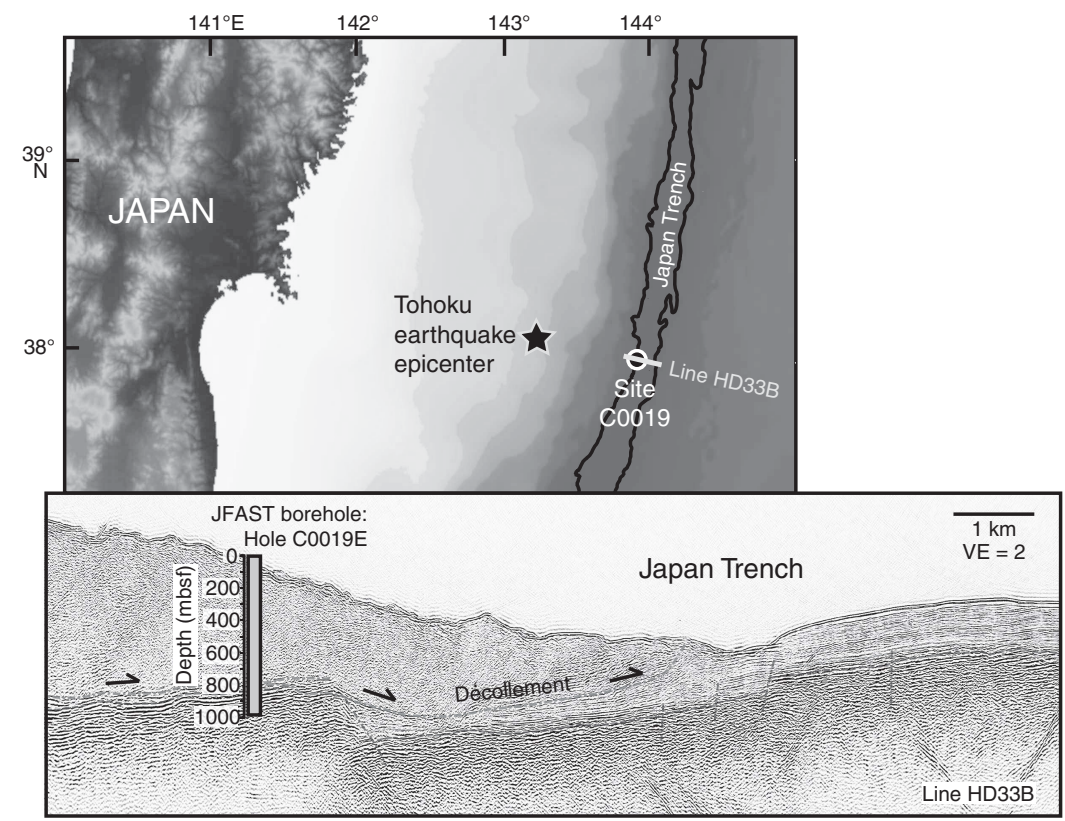


Figure F2. Schematic illustration of an idealized velocity step showing the role of individual rate- and statedependent friction parameters. Friction slip dependence in this case is zero.

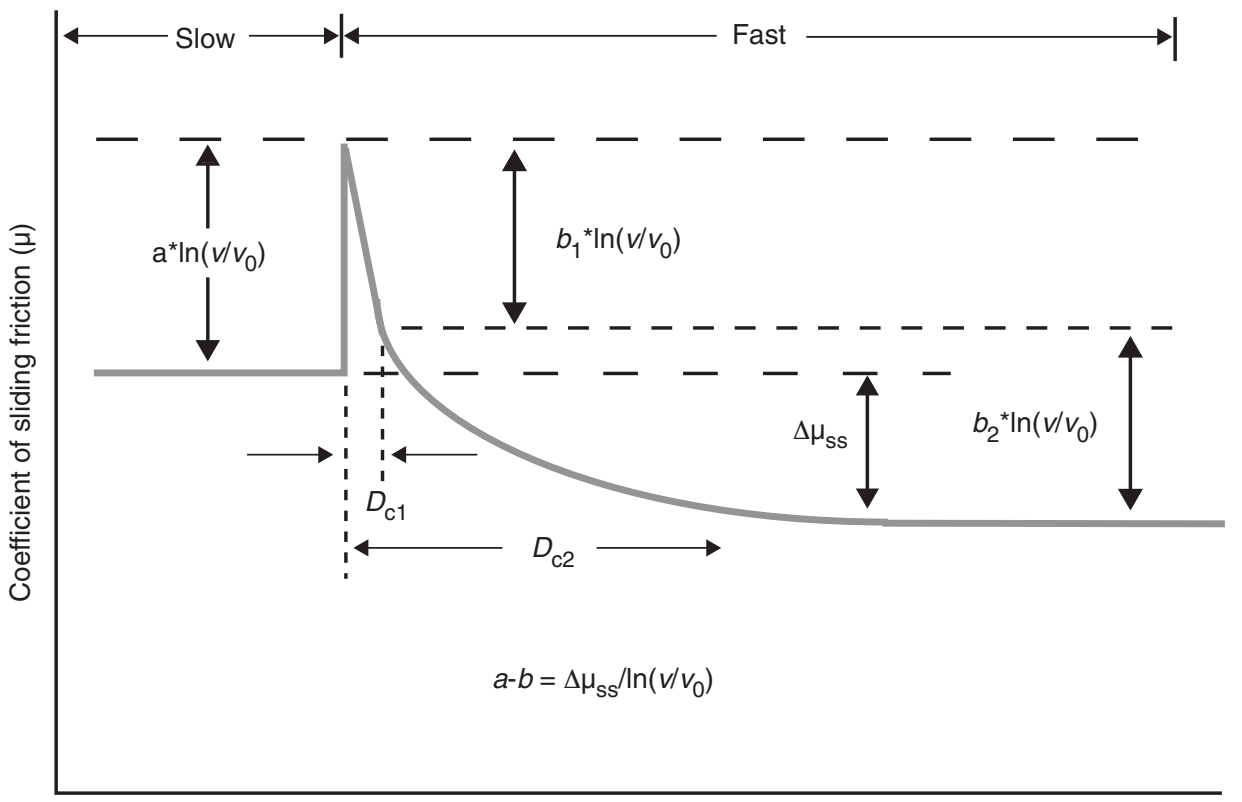

Displacement 
Figure F3. Example friction data for intact Sample 343-C0019E-12R-2. A. Complete friction-displacement curve showing where the velocity-stepping sequence was performed. Inset shows a schematic diagram of the singledirect-shear apparatus. B. Velocity-stepping sequence in A. C. Close-up view of the velocity step from 1 to 3 $\mu \mathrm{m} / \mathrm{s}$ (box in B). Experimental data (gray) is overlain by data determined by inverse modeling (black).

A

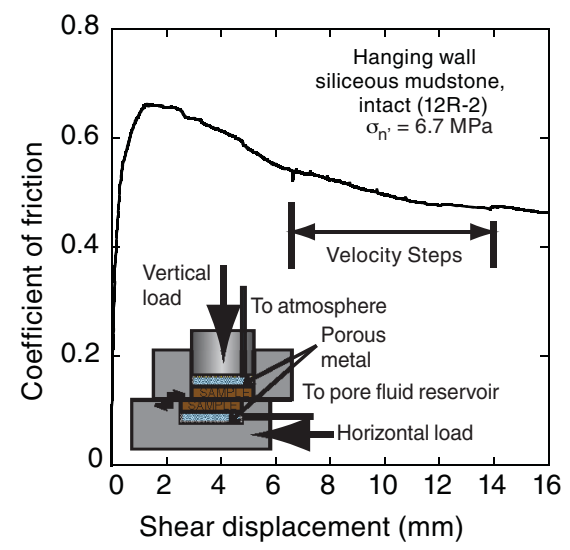

B



C

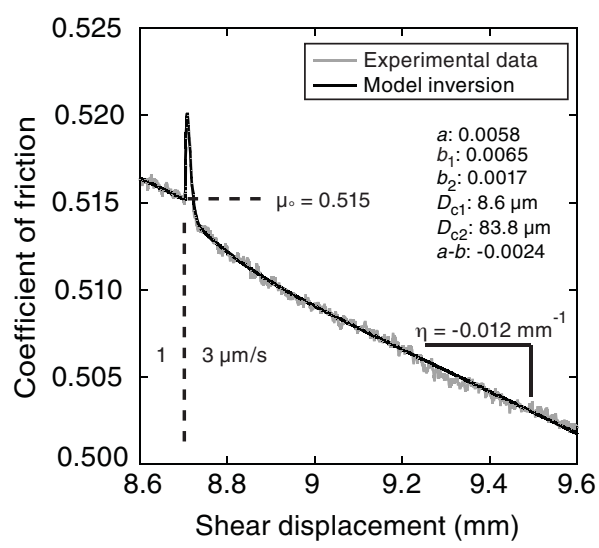


Figure F4. Rate- and state-dependent friction constitutive parameters (A) $a,(\mathbf{B}) b_{1}$ and $b_{2},(\mathbf{C}) D_{\mathrm{c} 1}$ and $D_{\mathrm{c} 2}$, (D) $a-b$ obtained by inverse modeling, and the measured parameters $(\mathbf{E}) \mu_{0}$ and $(\mathbf{F}) \eta$ for powdered samples as a function of depth Hole C0019E. Downhole lithology shown for reference (see the "Site C0019" chapter [Expedition 343/343T Scientists, 2013b]). Red line indicates samples from the fault zone, purple line indicates samples from the pelagic clay layer.

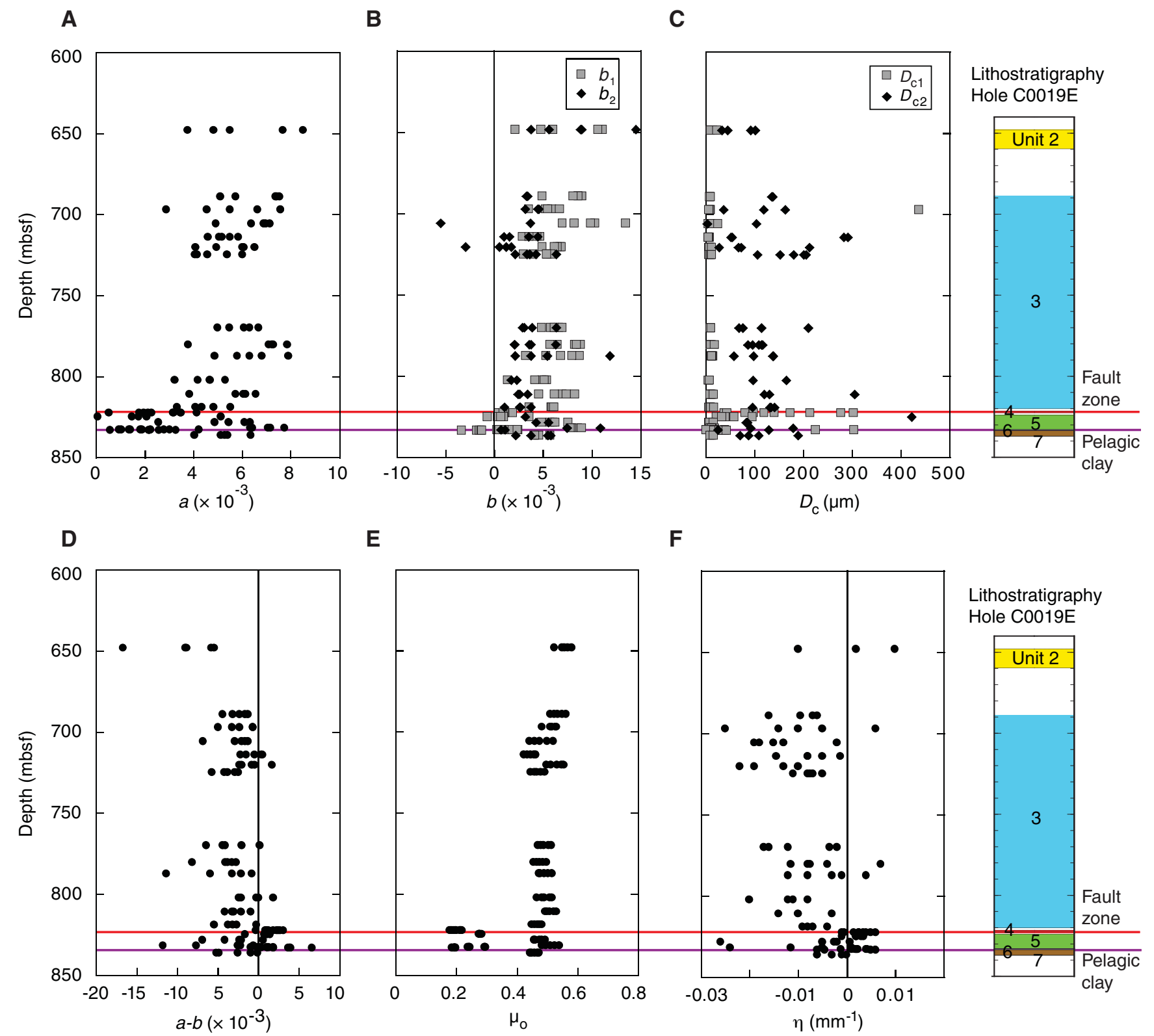


Figure F5. Rate- and state-dependent friction constitutive parameters (A) $a,(\mathbf{B}) b_{1}$ and $b_{2},(\mathbf{C}) D_{\mathrm{c} 1}$ and $D_{\mathrm{c} 2}$, (D) $a-b$ obtained by inverse modeling, and the measured parameters $(\mathbf{E}) \mu_{0}$ and $(\mathbf{F}) \eta$ for intact samples as a function of depth in Hole C0019E. Downhole lithology shown for reference (see the "Site C0019" chapter [Expedition 343/343T Scientists, 2013b]). Red line indicates samples from the fault zone, purple line indicates samples from the pelagic clay layer.

A

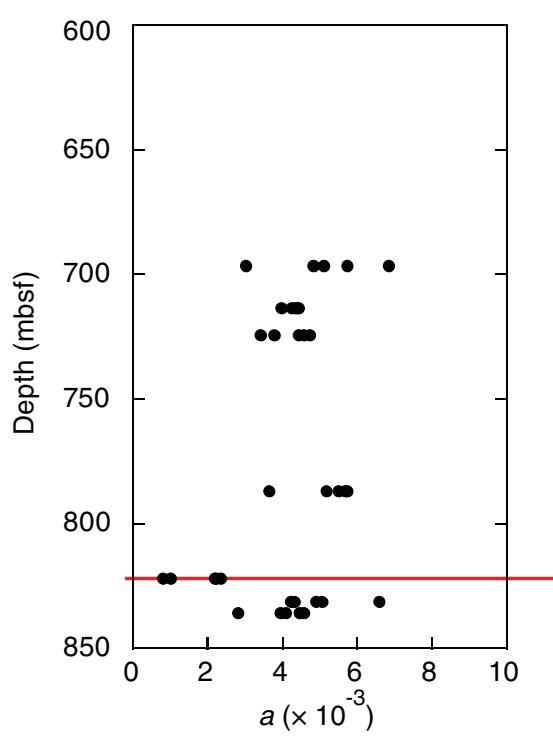

D

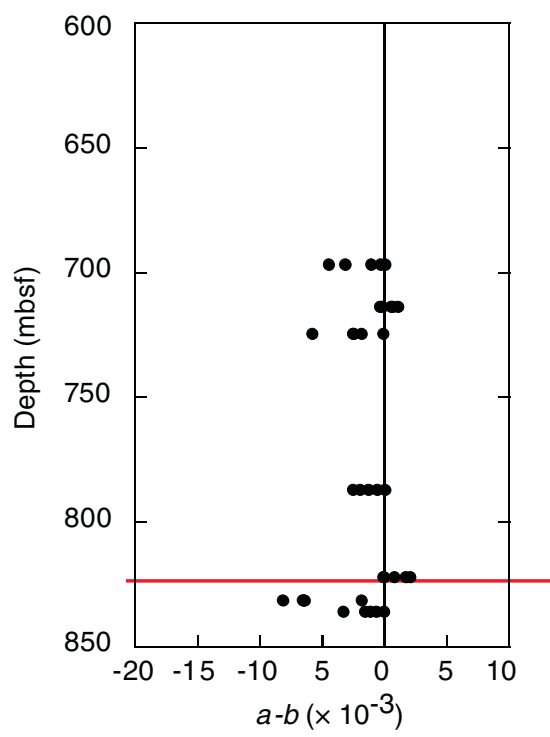

B

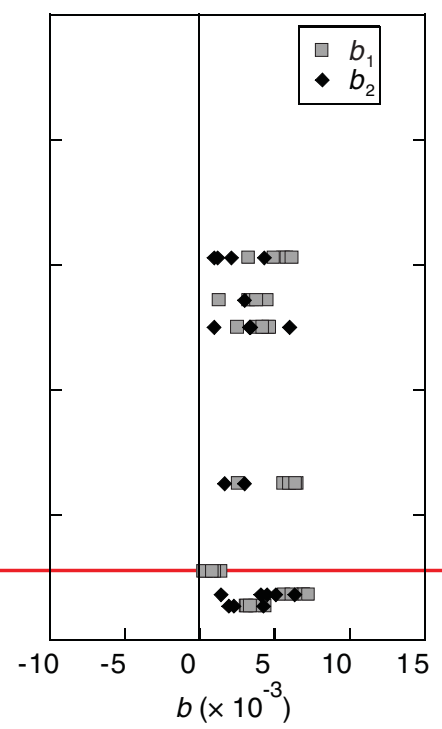

E

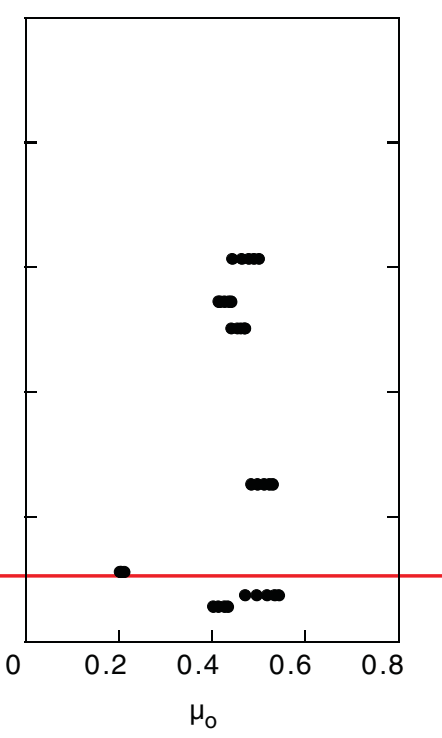

C

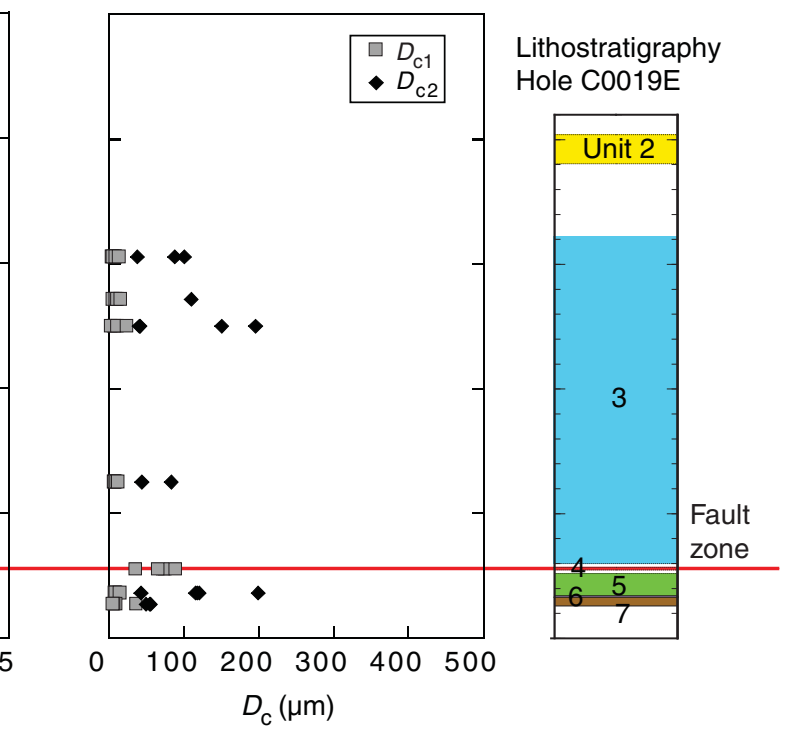

F

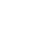

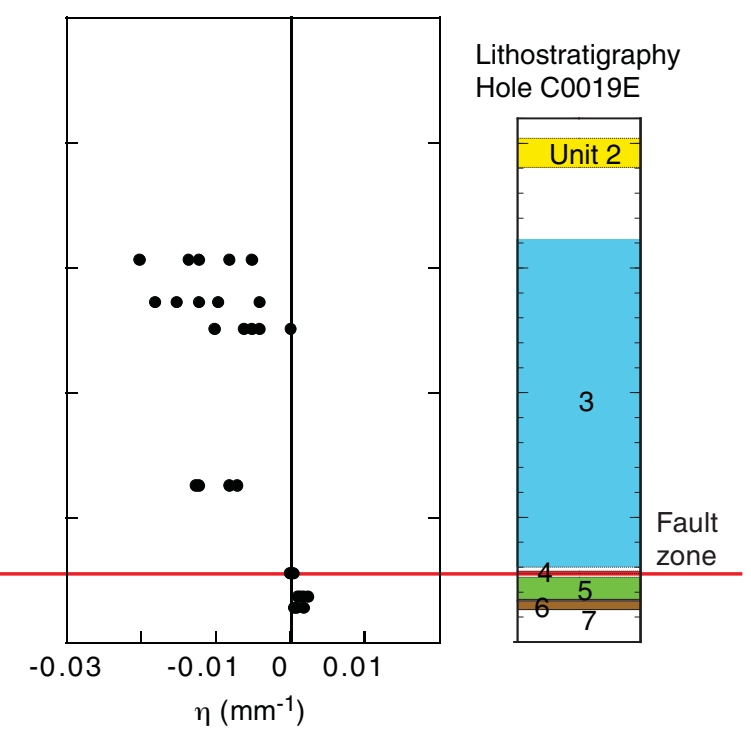


Table T1. Sample and experiment details, Hole C0019E.

\begin{tabular}{|c|c|c|c|c|c|c|}
\hline Experiment & Sample & Depth & $\begin{array}{l}\text { Lithologic } \\
\text { unit }\end{array}$ & Lithology & $\begin{array}{l}\text { Testing } \\
\text { state }\end{array}$ & $\begin{array}{c}\sigma_{n}{ }^{\prime} \text { during } \\
\text { testing }(\mathrm{MPa})\end{array}$ \\
\hline \multicolumn{7}{|c|}{ 343-C0019E- } \\
\hline B334 & $2 \mathrm{R}-1$ & 648.4 & 2 & Ashy mudstone & Powder & 4.9 \\
\hline B358 & $4 \mathrm{R}-1$ & 689.4 & 3 & Dark gray siliceous mudstone & Powder & 5.4 \\
\hline B351 & $5 \mathrm{R}-1$ & 697.2 & 3 & Dark gray siliceous mudstone & Intact & 5.5 \\
\hline B337 & $5 R-1$ & 697.2 & 3 & Dark gray siliceous mudstone & Powder & 5.5 \\
\hline B318 & $6 \mathrm{R}-2$ & 705.9 & 3 & Dark gray siliceous mudstone & Powder & 5.6 \\
\hline B356 & 7R-2 & 714.4 & 3 & Dark gray siliceous mudstone & Intact & 5.7 \\
\hline B365 & $7 R-2$ & 714.4 & 3 & Dark gray siliceous mudstone & Powder & 5.7 \\
\hline B320 & $8 \mathrm{R}-2$ & 720.4 & 3 & Dark gray siliceous mudstone & Powder & 5.8 \\
\hline B357 & $9 \mathrm{R}-1$ & 725.0 & 3 & Dark gray siliceous mudstone & Intact & 5.9 \\
\hline B366 & $9 \mathrm{R}-1$ & 725.0 & 3 & Dark gray siliceous mudstone & Powder & 5.9 \\
\hline B328 & 10R-1 & 770.2 & 3 & Dark gray siliceous mudstone & Powder & 6.5 \\
\hline B321 & $11 \mathrm{R}-\mathrm{CC}$ & 780.6 & 3 & Dark gray siliceous mudstone & Powder & 6.6 \\
\hline B359 & $12 \mathrm{R}-2$ & 787.4 & 3 & Dark gray siliceous mudstone & Intact & 6.7 \\
\hline B369 & $12 \mathrm{R}-2$ & 787.4 & 3 & Dark gray siliceous mudstone & Powder & 6.7 \\
\hline B329 & $13 R-2$ & 802.3 & 3 & Dark gray siliceous mudstone & Powder & 6.9 \\
\hline B370 & $14 \mathrm{R}-2$ & 811.2 & 3 & Dark gray siliceous mudstone & Powder & 7.0 \\
\hline B324 & $16 \mathrm{R}-1$ & 819.1 & 3 & Dark gray siliceous mudstone & Powder & 7.1 \\
\hline B344 & $17 R-1$ & 822.6 & 4 & Sheared scaly clay & $\begin{array}{l}\text { Millimeter- to centimeter- } \\
\text { scale pieces }\end{array}$ & 7.2 \\
\hline B378 & 17R-1 & 822.6 & 4 & Sheared scaly clay & Intact & 7.2 \\
\hline B353 & 17R-1 & 822.6 & 4 & Sheared scaly clay & Powder & 7.2 \\
\hline B325 & $18 \mathrm{R}-1$ & 824.9 & 5 & Brown siliceous mudstone & Powder & 7.2 \\
\hline B375 & $18 \mathrm{R}-1$ & 824.9 & 5 & Brown siliceous mudstone & Powder & 7.2 \\
\hline B373 & 19R-2 & 828.4 & 5 & Brown siliceous mudstone & Powder & 7.3 \\
\hline B350 & $20 \mathrm{R}-1$ & 831.9 & 5 & Brown siliceous mudstone & Intact & 7.3 \\
\hline B339 & $20 \mathrm{R}-1$ & 831.9 & 5 & Brown siliceous mudstone & Powder & 7.3 \\
\hline B361 & $20 \mathrm{R}-2$ & 833.0 & 6 & Pelagic clay (brown) & Powder & 7.3 \\
\hline B352 & $20 \mathrm{R}-2$ & 833.1 & 6 & Pelagic clay (pink) & Powder & 7.3 \\
\hline B362 & $20 \mathrm{R}-2$ & 833.3 & 6 & Pelagic clay (white) & Powder & 7.3 \\
\hline B333 & $21 R-1$ & 836.6 & 2 or $3^{*}$ & Dark gray siliceous mudstone & Intact & 7.4 \\
\hline B343 & $21 R-1$ & 836.6 & 2 or $3^{*}$ & Dark gray siliceous mudstone & Powder & 7.4 \\
\hline
\end{tabular}

* $=$ interpreted to have originated from a shallower unit. 
Table T2. Modeled constitutive friction parameters for powdered samples, Hole C0019E. (Continued on next two pages.)

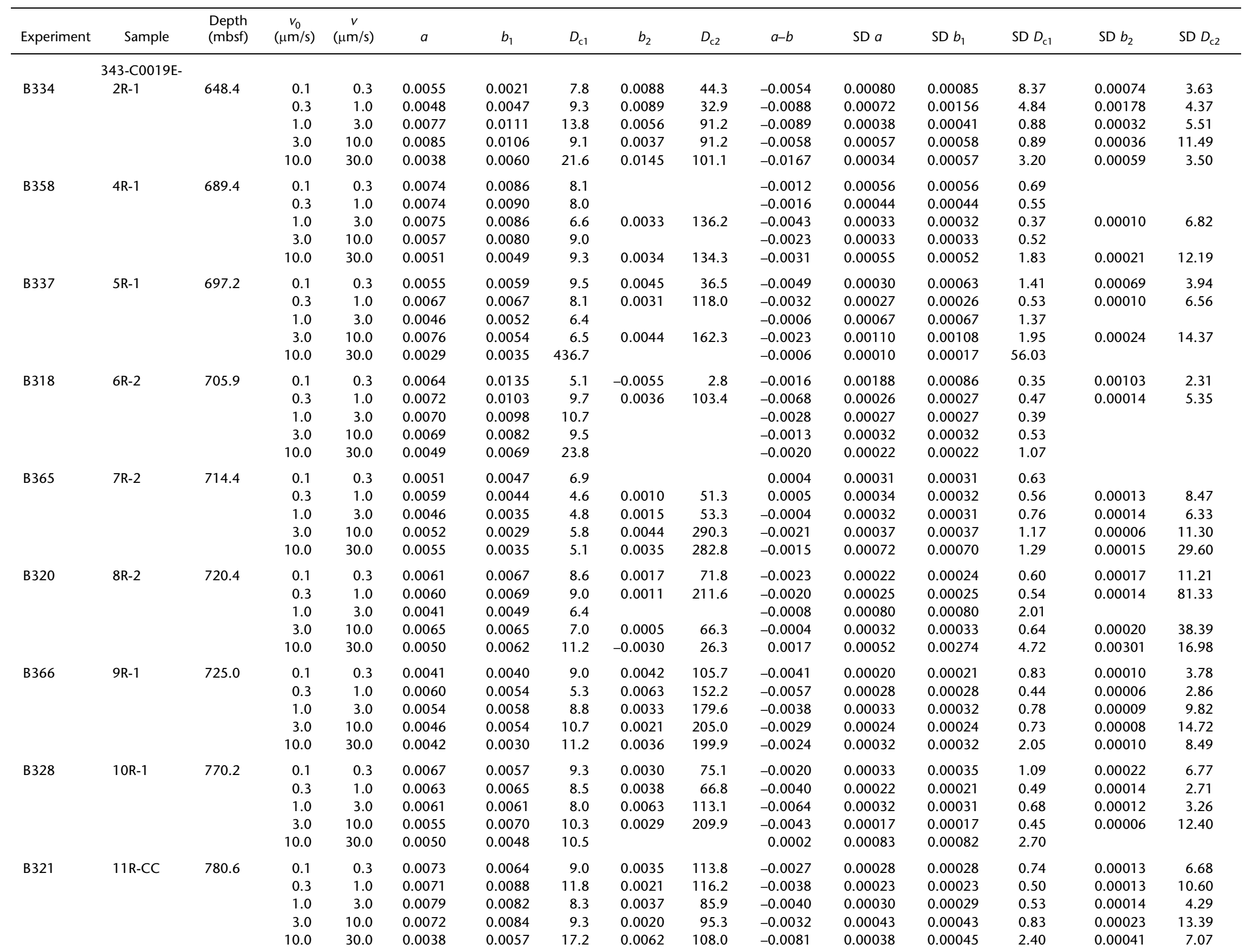


Table T2 (continued). (Continued on next page).

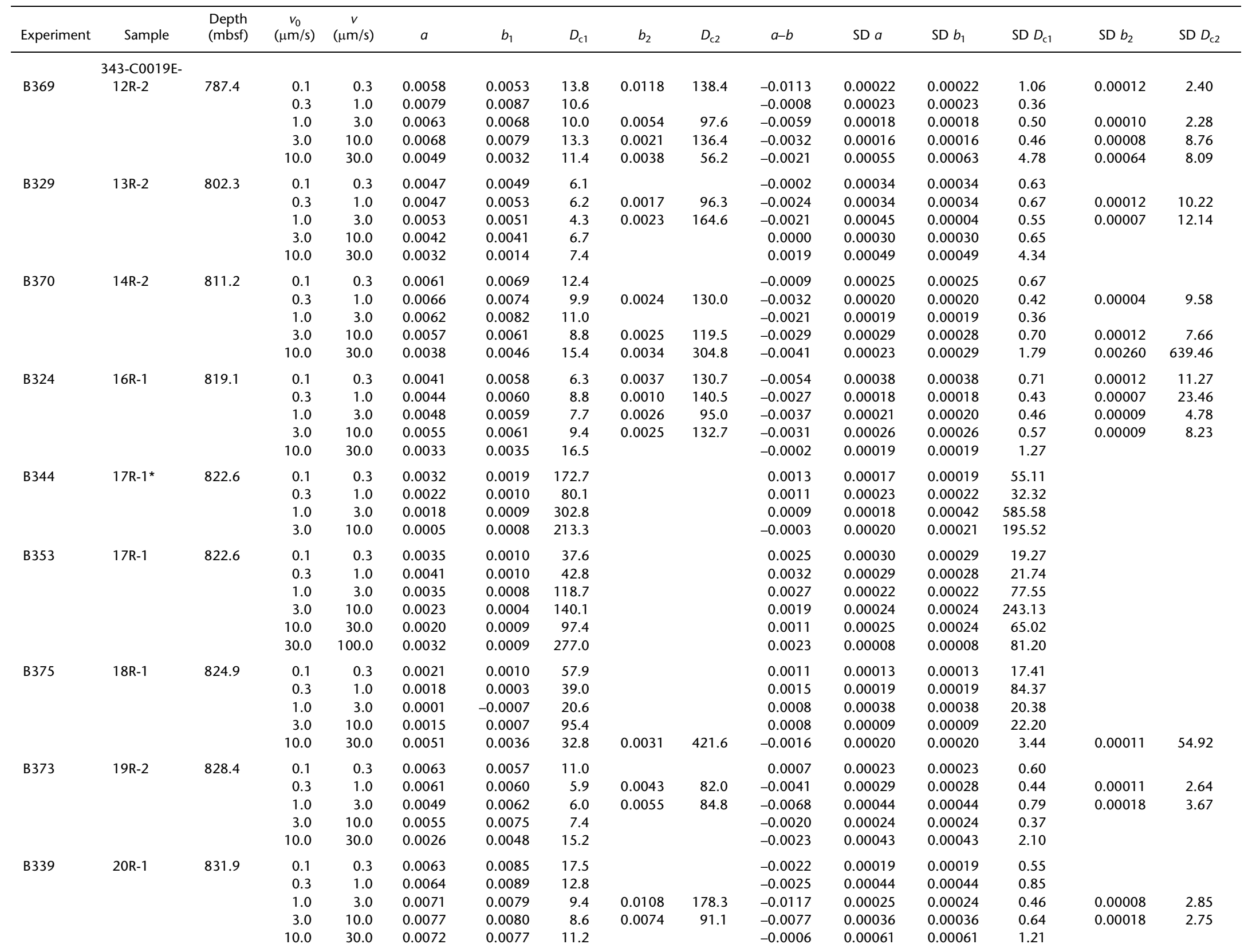




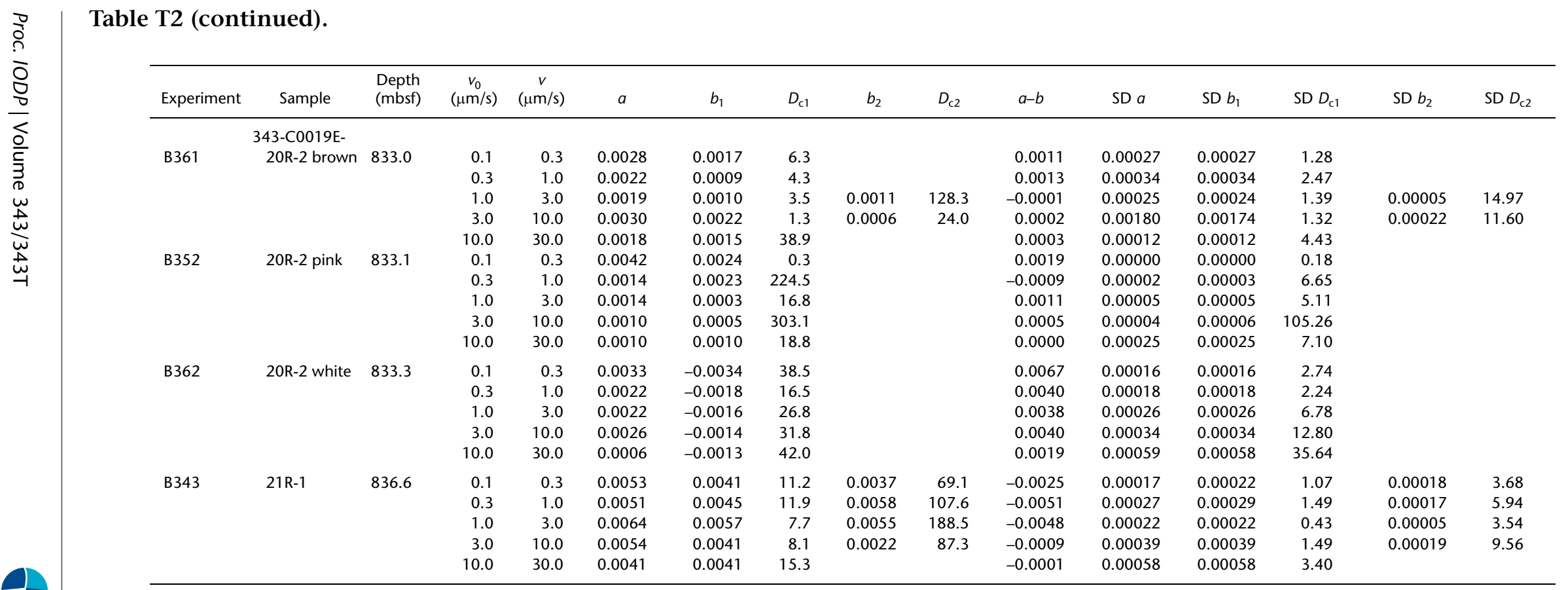

* $=$ tested as millimeter- to centimeter-scale pieces. SD = standard deviation. See text for parameter definitions. 
Table T3. Measured friction parameters for powdered samples, Hole C0019E. (Continued on next page.)

\begin{tabular}{|c|c|c|c|c|c|c|}
\hline Experiment & Sample & $\begin{array}{l}\text { Depth } \\
\text { (mbsf) }\end{array}$ & $\begin{array}{c}v_{o} \\
(\mu \mathrm{m} / \mathrm{s})\end{array}$ & $\begin{array}{c}v \\
(\mu \mathrm{m} / \mathrm{s})\end{array}$ & $\mu_{\mathrm{o}}$ & $\begin{array}{c}\eta \\
\left(\mathrm{mm}^{-1}\right)\end{array}$ \\
\hline & 343-C0019E- & & & & & \\
\hline \multirow[t]{5}{*}{ B334 } & $2 \mathrm{R}-1$ & 648.4 & 0.1 & 0.3 & 0.582 & 0.010 \\
\hline & & & 0.3 & 1.0 & 0.569 & 0.002 \\
\hline & & & 1.0 & 3.0 & 0.557 & 0.002 \\
\hline & & & 3.0 & 10.0 & 0.549 & -0.010 \\
\hline & & & 10.0 & 30.0 & 0.525 & -0.010 \\
\hline \multirow[t]{5}{*}{ B358 } & $4 \mathrm{R}-1$ & 689.4 & 0.1 & 0.3 & 0.563 & -0.016 \\
\hline & & & 0.3 & 1.0 & 0.549 & -0.016 \\
\hline & & & 1.0 & 3.0 & 0.535 & -0.006 \\
\hline & & & 3.0 & 10.0 & 0.523 & -0.010 \\
\hline & & & 10.0 & 30.0 & 0.512 & -0.007 \\
\hline \multirow[t]{5}{*}{ B337 } & $5 R-1$ & 697.2 & 0.1 & 0.3 & 0.532 & 0.006 \\
\hline & & & 0.3 & 1.0 & 0.529 & -0.010 \\
\hline & & & 1.0 & 3.0 & 0.518 & -0.005 \\
\hline & & & 3.0 & 10.0 & 0.512 & -0.025 \\
\hline & & & 10.0 & 30.0 & 0.483 & -0.014 \\
\hline \multirow[t]{5}{*}{ B318 } & $6 \mathrm{R}-2$ & 705.9 & 0.1 & 0.3 & 0.520 & -0.019 \\
\hline & & & 0.3 & 1.0 & 0.500 & -0.018 \\
\hline & & & 1.0 & 3.0 & 0.477 & -0.013 \\
\hline & & & 3.0 & 10.0 & 0.460 & -0.015 \\
\hline & & & 10.0 & 30.0 & 0.443 & -0.002 \\
\hline \multirow[t]{5}{*}{ B365 } & 7R-2 & 714.4 & 0.1 & 0.3 & 0.464 & -0.008 \\
\hline & & & 0.3 & 1.0 & 0.457 & -0.001 \\
\hline & & & 1.0 & 3.0 & 0.447 & -0.015 \\
\hline & & & 3.0 & 10.0 & 0.435 & -0.008 \\
\hline & & & 10.0 & 30.0 & 0.425 & -0.005 \\
\hline \multirow[t]{5}{*}{ B320 } & 8R2- & 720.4 & 0.1 & 0.3 & 0.556 & -0.010 \\
\hline & & & 0.3 & 1.0 & 0.548 & -0.019 \\
\hline & & & 1.0 & 3.0 & 0.533 & -0.022 \\
\hline & & & 3.0 & 10.0 & 0.514 & -0.013 \\
\hline & & & 10.0 & 30.0 & 0.499 & -0.013 \\
\hline \multirow[t]{5}{*}{ B366 } & 9R-1 & 725 & 0.1 & 0.3 & 0.492 & -0.011 \\
\hline & & & 0.3 & 1.0 & 0.480 & -0.007 \\
\hline & & & 1.0 & 3.0 & 0.468 & -0.005 \\
\hline & & & 3.0 & 10.0 & 0.459 & -0.008 \\
\hline & & & 10.0 & 30.0 & 0.447 & -0.008 \\
\hline \multirow[t]{5}{*}{ B328 } & 10R-1 & 770.2 & 0.1 & 0.3 & 0.515 & -0.012 \\
\hline & & & 0.3 & 1.0 & 0.505 & -0.016 \\
\hline & & & 1.0 & 3.0 & 0.489 & -0.002 \\
\hline & & & 3.0 & 10.0 & 0.480 & -0.004 \\
\hline & & & 10.0 & 30.0 & 0.471 & -0.017 \\
\hline \multirow[t]{5}{*}{ B321 } & $11 \mathrm{R}-\mathrm{CC}$ & 780.6 & 0.1 & 0.3 & 0.498 & -0.012 \\
\hline & & & 0.3 & 1.0 & 0.488 & -0.008 \\
\hline & & & 1.0 & 3.0 & 0.477 & -0.004 \\
\hline & & & 3.0 & 10.0 & 0.468 & -0.008 \\
\hline & & & 10.0 & 30.0 & 0.456 & 0.007 \\
\hline \multirow[t]{5}{*}{ B369 } & $12 \mathrm{R}-2$ & 787.4 & 0.1 & 0.3 & 0.516 & -0.001 \\
\hline & & & 0.3 & 1.0 & 0.503 & -0.012 \\
\hline & & & 1.0 & 3.0 & 0.491 & -0.008 \\
\hline & & & 3.0 & 10.0 & 0.478 & -0.003 \\
\hline & & & 10.0 & 30.0 & 0.473 & 0.004 \\
\hline \multirow[t]{5}{*}{ B329 } & $13 \mathrm{R}-2$ & 802.3 & 0.1 & 0.3 & 0.517 & -0.012 \\
\hline & & & 0.3 & 1.0 & 0.509 & -0.020 \\
\hline & & & 1.0 & 3.0 & 0.491 & -0.008 \\
\hline & & & 3.0 & 10.0 & 0.483 & -0.008 \\
\hline & & & 10.0 & 30.0 & 0.467 & -0.011 \\
\hline \multirow[t]{5}{*}{ B370 } & $14 \mathrm{R}-2$ & 811.2 & 0.1 & 0.3 & 0.531 & -0.014 \\
\hline & & & 0.3 & 1.0 & 0.522 & -0.014 \\
\hline & & & 1.0 & 3.0 & 0.510 & -0.010 \\
\hline & & & 3.0 & 10.0 & 0.501 & -0.003 \\
\hline & & & 10.0 & 30.0 & 0.494 & -0.003 \\
\hline
\end{tabular}


Table T3 (continued).

\begin{tabular}{|c|c|c|c|c|c|c|}
\hline Experiment & Sample & $\begin{array}{l}\text { Depth } \\
\text { (mbsf) }\end{array}$ & $\begin{array}{c}v_{\mathrm{o}} \\
(\mu \mathrm{m} / \mathrm{s})\end{array}$ & $\begin{array}{c}v \\
(\mu \mathrm{m} / \mathrm{s})\end{array}$ & $\mu_{\mathrm{o}}$ & $\begin{array}{c}\eta \\
\left(\mathrm{mm}^{-1}\right)\end{array}$ \\
\hline \multirow{6}{*}{ B324 } & 343-C0019E- & & & & & \\
\hline & $16 \mathrm{R}-1$ & 819.1 & 0.1 & 0.3 & 0.484 & -0.004 \\
\hline & & & 0.3 & 1.0 & 0.477 & -0.008 \\
\hline & & & 1.0 & 3.0 & 0.468 & -0.007 \\
\hline & & & 3.0 & 10.0 & 0.459 & -0.007 \\
\hline & & & 10.0 & 30.0 & 0.450 & -0.009 \\
\hline \multirow[t]{4}{*}{ B344 } & $17 R-1 *$ & 822.6 & 0.1 & 0.3 & 0.213 & 0.002 \\
\hline & & & 0.3 & 1.0 & 0.215 & 0.002 \\
\hline & & & 1.0 & 3.0 & 0.218 & 0.003 \\
\hline & & & 3.0 & 10.0 & 0.221 & 0.005 \\
\hline \multirow[t]{6}{*}{ B353 } & 17R-1 & 822.6 & 0.1 & 0.3 & 0.181 & 0.003 \\
\hline & & & 0.3 & 1.0 & 0.183 & -0.001 \\
\hline & & & 1.0 & 3.0 & 0.186 & 0.004 \\
\hline & & & 3.0 & 10.0 & 0.192 & 0.004 \\
\hline & & & 10.0 & 30.0 & 0.197 & 0.006 \\
\hline & & & 30.0 & 100.0 & 0.201 & -0.001 \\
\hline \multirow[t]{5}{*}{ B375 } & 18R-1 & 824.9 & 0.1 & 0.3 & 0.279 & 0.002 \\
\hline & & & 0.3 & 1.0 & 0.276 & -0.001 \\
\hline & & & 1.0 & 3.0 & 0.278 & 0.003 \\
\hline & & & 3.0 & 10.0 & 0.280 & 0.004 \\
\hline & & & 10.0 & 30.0 & 0.285 & 0.002 \\
\hline \multirow[t]{5}{*}{ B373 } & $19 \mathrm{R}-2$ & 828.4 & 0.1 & 0.3 & 0.495 & -0.026 \\
\hline & & & 0.3 & 1.0 & 0.483 & -0.002 \\
\hline & & & 1.0 & 3.0 & 0.476 & -0.005 \\
\hline & & & 3.0 & 10.0 & 0.462 & -0.003 \\
\hline & & & 10.0 & 30.0 & 0.457 & 0.001 \\
\hline \multirow[t]{5}{*}{ B339 } & 20R-1 & 831.9 & 0.1 & 0.3 & 0.540 & -0.024 \\
\hline & & & 0.3 & 1.0 & 0.526 & -0.024 \\
\hline & & & 1.0 & 3.0 & 0.512 & -0.005 \\
\hline & & & 3.0 & 10.0 & 0.496 & 0.001 \\
\hline & & & 10.0 & 30.0 & 0.484 & -0.012 \\
\hline \multirow[t]{5}{*}{ B361 } & 20R-2 brown & 833 & 0.1 & 0.3 & 0.295 & 0.002 \\
\hline & & & 0.3 & 1.0 & 0.296 & -0.001 \\
\hline & & & 1.0 & 3.0 & 0.296 & -0.001 \\
\hline & & & 3.0 & 10.0 & 0.296 & 0.004 \\
\hline & & & 10.0 & 30.0 & 0.297 & 0.002 \\
\hline \multirow[t]{5}{*}{ B352 } & 20R-2 pink & 833.1 & 0.1 & 0.3 & 0.238 & 0.004 \\
\hline & & & 0.3 & 1.0 & 0.243 & 0.001 \\
\hline & & & 1.0 & 3.0 & 0.243 & 0.002 \\
\hline & & & 3.0 & 10.0 & 0.244 & 0.002 \\
\hline & & & 10.0 & 30.0 & 0.246 & 0.002 \\
\hline \multirow[t]{5}{*}{ B362 } & 20R-2 white & 833.3 & 0.1 & 0.3 & 0.187 & 0.006 \\
\hline & & & 0.3 & 1.0 & 0.196 & -0.006 \\
\hline & & & 1.0 & 3.0 & 0.195 & -0.006 \\
\hline & & & 3.0 & 10.0 & 0.197 & -0.005 \\
\hline & & & 10.0 & 30.0 & 0.200 & 0.005 \\
\hline \multirow[t]{5}{*}{ B343 } & $21 R-1$ & 836.6 & 0.1 & 0.3 & 0.475 & 0.000 \\
\hline & & & 0.3 & 1.0 & 0.469 & -0.001 \\
\hline & & & 1.0 & 3.0 & 0.459 & -0.003 \\
\hline & & & 3.0 & 10.0 & 0.451 & -0.003 \\
\hline & & & 10.0 & 30.0 & 0.444 & -0.006 \\
\hline
\end{tabular}

* $=$ tested as millimeter- to centimeter-scale pieces. 


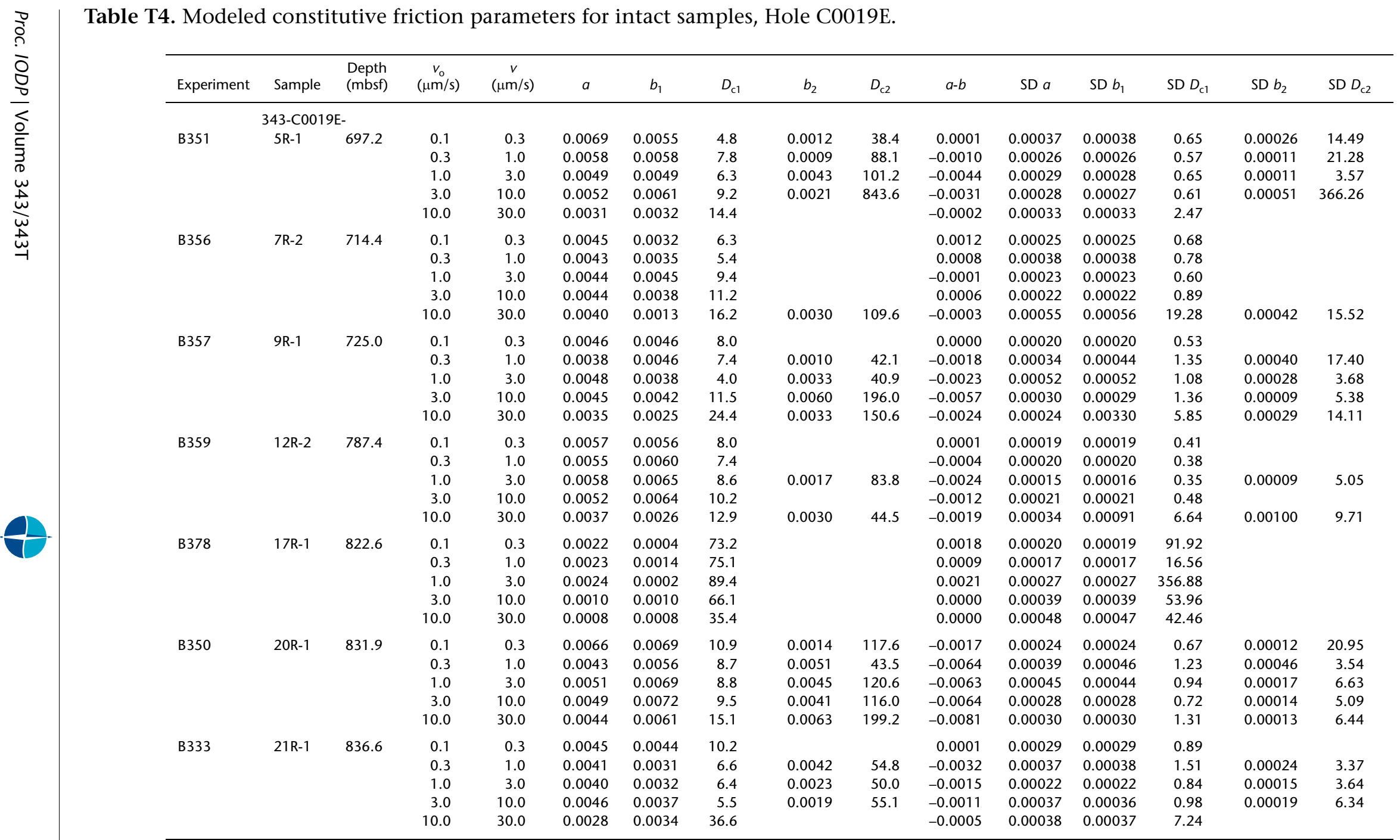

$\mathrm{SD}=$ standard deviation. See text for parameter definitions. 
Table T5. Measured friction parameters for intact samples, Hole C0019E.

\begin{tabular}{|c|c|c|c|c|c|c|}
\hline Experiment & Sample & $\begin{array}{l}\text { Depth } \\
\text { (mbsf) }\end{array}$ & $\begin{array}{c}v_{o} \\
(\mu \mathrm{m} / \mathrm{s})\end{array}$ & $\begin{array}{c}v \\
(\mu \mathrm{m} / \mathrm{s})\end{array}$ & $\mu_{\circ}$ & $\begin{array}{c}\eta \\
\left(\mathrm{mm}^{-1}\right)\end{array}$ \\
\hline \multicolumn{7}{|c|}{ 343-C0019E- } \\
\hline \multirow[t]{5}{*}{ B351 } & $5 \mathrm{R} 1$ & 697.2 & 0.1 & 0.3 & 0.503 & -0.0050 \\
\hline & & & 0.3 & 1.0 & 0.492 & -0.0120 \\
\hline & & & 1.0 & 3.0 & 0.481 & -0.0080 \\
\hline & & & 3.0 & 10.0 & 0.466 & -0.0135 \\
\hline & & & 10.0 & 30.0 & 0.447 & -0.0200 \\
\hline \multirow[t]{5}{*}{ B356 } & 7R2 & 714.4 & 0.1 & 0.3 & 0.445 & -0.0095 \\
\hline & & & 0.3 & 1.0 & 0.439 & -0.0120 \\
\hline & & & 1.0 & 3.0 & 0.430 & -0.0150 \\
\hline & & & 3.0 & 10.0 & 0.420 & -0.0180 \\
\hline & & & 10.0 & 30.0 & 0.417 & -0.0040 \\
\hline \multirow[t]{5}{*}{ B357 } & 9R1 & 725 & 0.1 & 0.3 & 0.474 & 0.0002 \\
\hline & & & 0.3 & 1.0 & 0.472 & -0.0040 \\
\hline & & & 1.0 & 3.0 & 0.465 & -0.0060 \\
\hline & & & 3.0 & 10.0 & 0.457 & -0.0050 \\
\hline & & & 10.0 & 30.0 & 0.444 & -0.0100 \\
\hline \multirow[t]{5}{*}{ B359 } & $12 \mathrm{R} 2$ & 787.4 & 0.1 & 0.3 & 0.534 & -0.0080 \\
\hline & & & 0.3 & 1.0 & 0.526 & -0.0125 \\
\hline & & & 1.0 & 3.0 & 0.515 & -0.0120 \\
\hline & & & 3.0 & 10.0 & 0.501 & -0.0120 \\
\hline & & & 10.0 & 30.0 & 0.488 & -0.0070 \\
\hline \multirow[t]{5}{*}{ B375 } & 17R1 & 822.6 & 0.1 & 0.3 & 0.205 & 0.0006 \\
\hline & & & 0.3 & 1.0 & 0.205 & 0.0006 \\
\hline & & & 1.0 & 3.0 & 0.207 & 0.0003 \\
\hline & & & 3.0 & 10.0 & 0.209 & 0.0003 \\
\hline & & & 10.0 & 30.0 & 0.215 & 0.0001 \\
\hline \multirow[t]{5}{*}{ B350 } & 20R1 & 831.9 & 0.1 & 0.3 & 0.547 & 0.0015 \\
\hline & & & 0.3 & 1.0 & 0.537 & 0.0015 \\
\hline & & & 1.0 & 3.0 & 0.521 & 0.0020 \\
\hline & & & 3.0 & 10.0 & 0.498 & 0.0025 \\
\hline & & & 10.0 & 30.0 & 0.474 & 0.0012 \\
\hline \multirow[t]{5}{*}{ B333 } & $21 \mathrm{R} 1$ & 836.6 & 0.1 & 0.3 & 0.438 & 0.0020 \\
\hline & & & 0.3 & 1.0 & 0.429 & 0.0020 \\
\hline & & & 1.0 & 3.0 & 0.418 & 0.0020 \\
\hline & & & 3.0 & 10.0 & 0.405 & 0.0007 \\
\hline & & & 10.0 & 30.0 & 0.405 & 0.0010 \\
\hline
\end{tabular}

